\section{Atividades em Polímeros da AEASP}

Parabéns pela cobertura sobre reciclagem. Informamos que a AEASP - Associação de Engenheiros Agrônomos do Estado de São Paulo - coordena dois programas relacionados aos polímeros:

1) Programa de Plasticultura: visa difundir a técnica agronômica e comercial de produção de culturas protegidas. Tem abrangência nacional e é realizada com a colaboração de empresas do setor e do SEBRAE. Formamos técnicos e damos treinamento a agricultores. Para este ano, estão previstas as instalações de unidades de demonstração, além da participação no Agrishow'97, a melhor e maior feira dinâmica da Agricultura. Neste progama ressaltamos a participação das petroquímicas Triunfo, Politeno e OPP Petroquímica S/A.

2) Projeto Piloto de Destino Final de Embalagens Vazias de Agrotóxico: Trata-se de projeto piloto em fase final, que visa introduzir a técnica de se lavar 3 (três) vezes as embalagens vazias de defensivos agrícolas, colocando a água no tanque de pulveriza- ção, e depois encaminhá-las para a reciclagem em empresas com autorização da CETESB.

Certamente, empresas e sociedade devem estar juntas nestas ações

Eng $^{\circ}$ Agr $^{\circ}$ Guido José da Costa Presidente da AEASP - São Paulo

\section{Agradecimento pela Publicação de Artigo}

Gostaríamos de agradecer pela publicação sobre a atuação de nossa empresa na área de reciclagem de polímeros no artigo "Reciclagem de Polímeros: Situação Brasileira"na revista "Polímeros: Ciência e Tecnologia", ano VI - no 4.

Acreditamos que iniciativas como esta impulsionam a troca de conhecimentos e atualização quanto às novas tecnologias que surgem na área de reciclagem de polímeros.

Rudolf Fraunhofer Hansatec do Brasil - São Paulo 